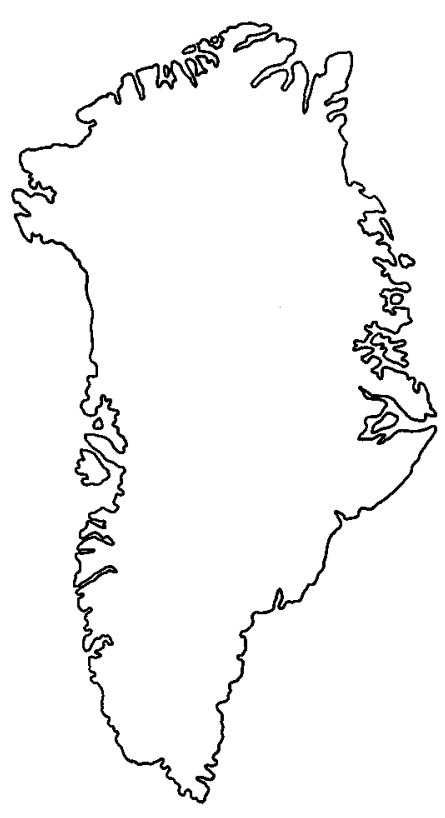

\title{
Silurian trilobites from Kap Schuchert, Washington Land, western North Greenland
}

\author{
Philip D. Lane and Robert M. Owens
}

\begin{abstract}
Nine forms of trilobites are described from the uppermost Llandovery or lowest Wenlock of Washington Land, western North Greenland of which the following taxa are new: - Ligiscus arcanus gen. et sp. nov., Xenocybe ebyconex sp. nov., Sphaerexochus centeo sp. nov. and Hyrokybe meliceris sp. nov. The faunal links, age and composition of the fauna are discussed.

P. D. L., Department of Geology, University of Keele, Keele, Staffs, ST5 5BG. U. K.

R.M.O., Department of Geology, National Museum of Wales, Cardiff CF1 3NP. Wales, U.K.
\end{abstract}

The trilobites described below were recovered from two small (c. $2 \mathrm{~kg}$ ) blocks of predominantly very pale grey biosparite. These blocks were collected in August 1976 by J. M. Hurst (Geological Survey of Greenland) from near the top of the section immediately south of Kap Schuchert, Washington Land, western North Greenland (Hurst, 1980, fig. 24, section A, see fig: 1, herein). Such biosparites occur as blocks in the breccias of the Lafayette Bugt Formation (Hurst, 1980, p. 80) and are considered to be derived from the partly coeval Pentamerus Bjerg Formation (Hurst, 1980, p. 29). The two blocks (GGU samples 216855 and 216856) were collected about $1 \mathrm{~m}$ stratigraphically apart although their original stratigraphic relationship cannot be ascertained. Trilobites from the two samples are considered as a single fauna (Table 1).

Sample 216855 , although largely pale grey biosparite, was partly composed of the matrix of the breccias - a darker grey, much finer grained limestone more typical of the Lafayette Bugt Formation. There were no differences between the conodont faunas recovered from the two lithologies in this sample (R. J. Aldridge, Nottingham University, personal communication). It was from the darker, finer sediment of GGU sample 216855 that the ostracod Monoceratella mazos Lane (1980) was described.

The terminology and techniques employed are those described in Lane $(1979$, p. 5) and Owens (1973b, p. 4).

\section{Age of the fauna}

The biostratigraphic information gained from the Silurian trilobites described herein is in accordance with previous suggestions that the age of the samples is close to the Llandovery/ Wenlock boundary. The samples were presumably collected from the 'limestone conglomer- 


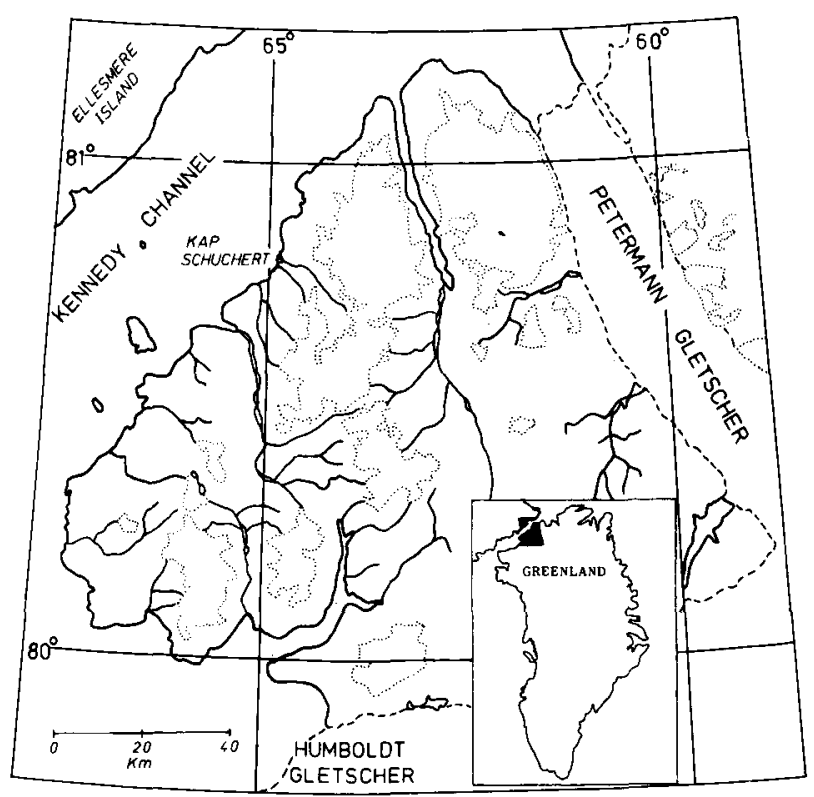

Fig. 1. Locality map.

ates' of Unit 12 in the Kap Schuchert section of Norford (1972, figs 3, 5, 7); graptolites indicating an uppermost Llandovery ( $M$. spiralis Zone) age were obtained from Geological Survey of Canada locality 73973, sited c. 2-5 m below Norford's Unit 12. Conodonts obtained from both samples place the conglomerate undoubtedly in the amorphognathoides Zone and possibly in its upper part (Aldridge in Lane, 1980). Hurst's (1980) opinion that on

Table 1. Distribution of non-thoracic exoskeletal parts of trilobites in GGU collections from Kap Schuchert

\begin{tabular}{|c|c|c|c|c|c|c|c|c|c|c|c|c|c|c|c|c|c|c|}
\hline & & & 216 & 6855 & & & & & 2168 & 856 & & & & & Comt & bines & & \\
\hline & 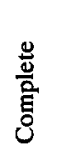 & $\frac{\frac{\pi}{\pi}}{\frac{\pi}{0}}$ & 莺 & 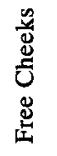 & 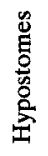 & $\frac{\sqrt[G]{3}}{3}$ & 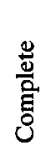 & $\begin{array}{l}\frac{\pi}{\pi} \\
\frac{\pi}{0} \\
\end{array}$ & 芯 & 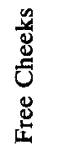 & 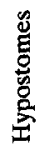 & 总 & 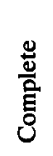 & $\frac{\frac{\pi}{3}}{\frac{0}{0}}$ & 莺 & 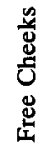 & $\begin{array}{l}\text { \& } \\
\text { E⿱ } \\
0 \\
\text { : } \\
\text { 空 }\end{array}$ & 总 \\
\hline Bumastus? sp. ........... & - & - & - & 1 & - & - & - & - & - & - & - & - & - & - & - & 1 & - & - \\
\hline Meroperix aquilonaris ...... & - & 3 & 9 & 11 & 7 & 39 & - & 3 & 13 & 2 & 41 & 14 & - & 6 & 22 & 13 & 11 & 53 \\
\hline Ligiscus arcanus .......... & - & 5 & - & - & - & 1 & - & 2 & 1 & - & - & - & - & 7 & 1 & - & - & 1 \\
\hline Xenocybe ebyconex ........ & - & 3 & 117 & 53 & 1 & 116 & 3 & 3 & 79 & 26 & 17 & 74 & 3 & 6 & 196 & 79 & 2 & 190 \\
\hline Scotoharpes sp. .......... & - & 1 & - & - & - & - & - & - & - & - & - & - & - & 1 & - & - & - & - \\
\hline Sphaerexochus centeo ...... & - & - & 49 & 1 & 6 & 21 & - & 1 & 46 & 2 & 3 & 6 & - & 1 & 95 & 3 & 9 & 27 \\
\hline Hyrokybe meliceris ....... & - & 3 & - & - & 1 & - & - & - & - & - & - & - & - & 3 & - & - & 1 & - \\
\hline ?Dicranogmus sp. . ........ & - & - & 1 & - & 1 & 2 & - & 1 & - & - & - & 1 & - & 1 & 1 & - & 1 & 3 \\
\hline Ceratocephala cf. C. bicuspis & - & 2 & - & 1 & - & - & - & - & - & - & - & - & - & 2 & - & 1 & - & - \\
\hline
\end{tabular}


regional and sedimentological grounds the conglomerate is not younger than Telychian (C6) is consistent with the biostratigraphical data. Here, confirmatory evidence for such an age is given by the presence of the trilobite Meroperix aquilonaris (Whiteaves, 1904) which occurs in the Attawapiskat Formation of the Hudson Bay Lowlands, Canada, considered by Norford (1981, p. 3, text figs 2,3) to be largely of upper Llandovery, but partly of low Wenlock age. Further evidence, presented with less confidence, may be afforded by forms left in open nomenclature: Ceratocephala cf. C. bicuspis and ?Dicranogmus sp. indicate links with low Wenlock and Llandovery/Wenlock boundary rocks of Gotland, Sweden and Kronprins Christian Land, eastern North Greenland respectively.

\section{Composition of the fauna}

Table 1 shows the distribution of the non-thoracic exoskeletal parts of trilobites recovered from the two samples. In this lithology, the exoskeleton may adhere either to the internal mould (usually, for example, in scutelluids and proetids) or to the external (almost always in Sphaerexochus). Counting was therefore achieved by considering only 'positive' or convex moulds, and noting only those elements of which more than half was present.

Thoracic segments of Xenocybe ebyconex are extremely common in the collections; those of other taxa are very rare. The $X$. ebyconex segments often occur articulated in groups of 5 to 10 and may be attached to a pygidium or cranidium, although complete specimens are rare. The three 'complete' specimens of this species recorded from GGU sample 216856 in fact lack the free cheeks and probably also the rostral plate and hypostome; they are therefore probably moults. To include the thoracic segments in the counts would have greatly biased the numbers towards the proetid. For instance in GGU sample 216855 at least 172 segments were counted in 29 groups (average about 6), with very few single segments noted; single segments are delicate and may have been relatively easily broken. Segments of Meroperix and Sphaerexochus were also seen, but in much smaller total numbers and usually as single elements.

The decision to ignore thoracic segments in the count seems appropriate since the cephalon + cranidium: pygidium ratio of Xenocybe ebyconex in the two collections approaches unity. This, together with the still articulated large portions of thorax, and the great range of size of individuals, indicates minimal transport, at least for this species.

The generic composition of the trilobite fauna is similar to that of other carbonate buildup trilobite faunas of broadly similar age, such as those described by Lane $(1972,1979)$ and Norford (1981) and those upon which Mikulic (1981) made general comments. The proportions of genera present (Table 2), however, are different in the approximately two-thirds presence of the single proetid species. As discussed below under Xenocybe, this genus has previously only been recorded from the late Ashgill carbonate sequences of Sweden and U.S.S.R. Significantly, the general morphology displayed by Xenocybe is repeated by a number of proetids in carbonate buildup sequences of Devonian and Carboniferous age.

The occurrence of smooth, effaced trilobites in such environments has been discussed elsewhere (e.g. Lane, 1972). Sphaerexochus, however, as compared to its presumed ancestors in the Cheiruridae, is typified by its great convexity, although some furrows of the glabella and thorax are effaced. A detailed functional morphology of members of the genus has not been undertaken but they are commonly abundant in carbonate buildup sequences (e.g., Lowenstam, 1957). Although the appendages are not known, the high length: width 
Table 2. Proportional representation of trilobites in GGU collections from Kap Schuchert

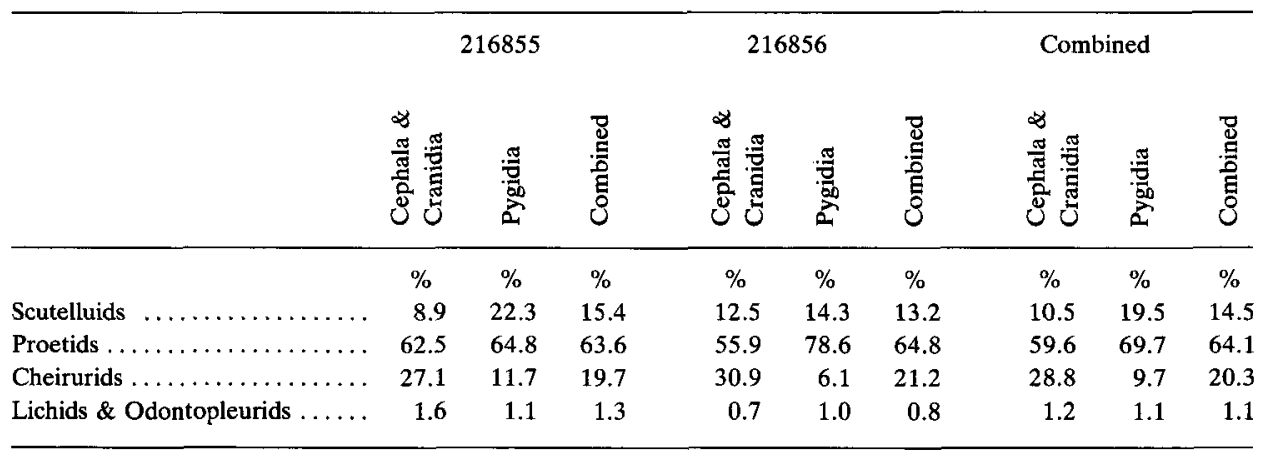

ratio of the entire exoskeleton and the disposition of the hypostome argue against a benthic mode of life.

A last feature of note in this small fauna is the homoeomorphy displayed by the cephala of ?Dicranogmus sp. and Hyrokybe meliceris, with their great convexity, pendent cheeks and coarse sculpture which helps obliterate some of the furrows.

\section{Systematic descriptions}

Family Scutelluidae Richter \& Richter, 1925

Diagnosis. See Lane \& Thomas (1978, p. 9).

Genus Bumastus Murchison, 1839

Type species. By monotypy; Bumastus barriensis Murchison, 1839, from the Wenlock Series, West Midlands, Britain.

Bumastus? sp.

Plate 3, fig. 3

Figured material. MGUH 15.355 (free cheek).

Discussion. A small, smooth, convex free cheek which lacks a genal spine and has a narrow eye socle and strip-like visual surface may belong to Bumastus.

Genus Meroperix Lane, 1972

Type species. By original designation; Meroperix ataphrus Lane, 1972, from the upper Llandovery or lower Wenlock of Kronprins Christian Land, eastern North Greenland.

Diagnosis. See Lane (1972, p. 343). 

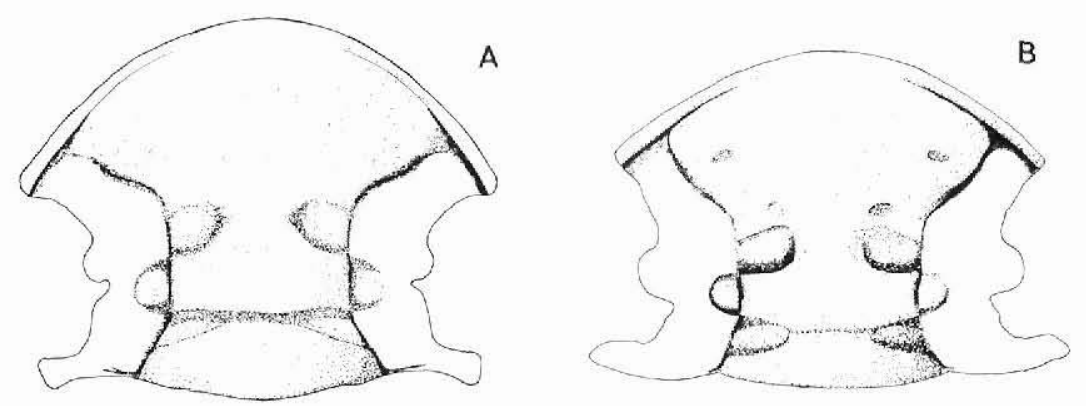

Fig. 2. Comparison of cranidia of Meroperix ataphrus (A) and M. aquilonaris (B), both about $\times 3$. Explanation in discussion of latter species.

\section{Meroperix aquilonaris (Whiteaves, 1904) \\ Plate 1, figs 1-11; Fig. 2b}

1904 Bronteus aquilonaris, sp. nov., Whiteaves, p. 58.

1906 Bronteus aquilonaris Whiteaves; Whiteaves, p. 267, pl. 42, fig. 2.

1915 Goldius aquilonaris (Whiteaves); Bassler, p. 558.

1919 Bronteus aquilonarius [sic] Whiteaves; Savage \& Van Tuyl, p. 362.

1981 Meroperix aquilonaris (Whiteaves, 1904); Norford, p. 6, pl. 5, figs 1-13, 15; fig. 4b.

Figured material. MGUH 15.356-8 (cephala); MGUH 15.359 (free cheek); MGUH 15.360 (hypostome); MGUH 15.361 (thoracic segments); MGUH 15.362-6 (pygidia).

Other material. See Table 1.

Discussion. Norford (1981, p. 6, pl. 5, figs 1-13, 15) recently redescribed this species from type and newly collected material from the late Llandovery and early Wenlock Attawapiskat Formation of the northern part of Ontario and Manitoba, Canada. It closely resembles the type species $M$. ataphrus but, in addition to the distinguishing characters noted by Norford, the type species has the posterior part of the glabella relatively more slender and parallelsided, and the axial furrow adjacent to its anterior part diverges at a greater angle forwards; the occipital, lateral and $1 \mathrm{G}$ muscle impressions are much less distinctly impressed, and $2 \mathrm{G}$, $3 \mathrm{G}$ and the pygidial axial muscle impressions more distinctly marked (fig. 2). In addition, in $M$. aquilonaris the glabella in the transverse line across $1 \mathrm{G}$ is trilobed in profile as a consequence of the deep impression of the posterior and adaxial parts of these large muscle impressions. $M$. ataphrus has a hypostome which is relatively a little longer with an indistinctly developed and much longer (sag.) posterior lobe of the middle body; its posterior margin is convex backwards rather than transverse.

The Canadian and Washington Land material of this form seems only to differ consistently in the size of the $2 \mathrm{G}$ muscle impression, which in the former is larger. However, the position of $2 \mathrm{G}$ is identical in the material from the two areas and this single character, when weighed against the overwhelming similarities, is not considered to be even of subspecific importance. 


\section{Genus Ligiscus gen. nov.}

Derivation of name. Latin, 'small grubbing mattock', alluding to the outline of the glabella. Type species. L. arcanus gen. et sp. nov.

Diagnosis. Effaced scutelluid with (in dorsal view) axial furrows diverging backwards little over the posterior one-sixth of their course, diverging more strongly forwards over anterior one-third, and failing to reach anterior margin. 1G largest muscle impression, longer (exs.) than wide (tr.); $2 \mathrm{G}$ smaller and very close to $1 \mathrm{G} ; 3 \mathrm{G}$ smallest and remote. Glabella with median keel which reaches from behind the level of $1 \mathrm{G}$ to near the anterior margin. Visual surface large and inflated, about one-third sagittal length of the cranidium, reaching from mid occipital muscle impression to anterior of lateral muscle impression. Tubercle present far back on glabella, close to posterior margin. Anterior section of facial suture runs less obliquely outwards forwards than the axial furrow (in dorsal view). Rostral plate with posteromedial elevation, about three times wider (tr.) than long (sag.). Pygidium incompletely known, highly effaced, with five pairs of pleural ribs weakly indicated at least on the internal mould.

Discussion. This extensive diagnosis is presented in an attempt to differentiate this taxon from similar effaced forms which exhibit a variety of characters found to be useful at different taxonomic levels. Ligiscus, in overall proportions of cephalon and pygidium, bears most resemblance to Litotix Lane \& Thomas in Thomas, 1978. Ligiscus differs from that genus as follows: the less convex caphalon makes the glabella appear much narrower (tr.) in dorsal view; the glabellar shape also differs in being almost parallel-sided over the posterior two-thirds. In dorsal view, the axial furrows are distinct almost to the anterior margin, and an anterior pit is lacking. The eye is a much less well pronounced feature, and the visual surface is oval and inflated. The patterns of glabellar muscle impressions show many differences; in Ligiscus the occipital muscle impression is transversely elongate and does not transversely overlap with the extent of the lateral muscle impression; $1 \mathrm{G}$ is proportionally much larger and more clearly impressed (on internal moulds particularly), the $2 \mathrm{G}$ pair is subcircular, closer together and farther forward and $3 \mathrm{G}$ is much the smallest of the group. Although the pygidium is of similar proportions, the complex array of axial muscle impressions is an obvious difference; the clear but weak ribs and furrows, the lack of strong terrace ridges over the whole of the dorsal surface, and the lack of an anterolateral depression further serve to distinguish the two taxa. The similarity of the two genera is therefore thought to be superficial; differences in some characters (shape of glabella and its muscle pattern, anterior pit, pygidial axis muscle pattern) are considered worthy of generic distinction.

Other effaced scutelluid genera are most easily distinguished from Ligiscus by a combination of the characters of overall convexity, glabellar shape and muscle pattern, size, morphology and position of eye, lack of genal spine and in the pygidium, size and muscle pattern of pygidial axis and lack of even weak ribbing of the pleural areas. 


\section{Ligiscus arcanus gen. et sp. nov.}

Plate 3, figs 4-8; Fig. 3

Derivation of nume. Latin, 'secret', referring to its systematic affinities.

Figured material. Holotype, MGUH 15.367 (cephalon). Paratypes, MGUH 15.368,9 (cephala); MGUH 15.370 (cranidium); MGUH 15.371 (pygidium).

Other material. See Table 1.

Diagnosis. As for genus.

Description. Cephalon convex, two-thirds as long (sag.) as wide across the posterior margin (tr.). Smooth curve of anterior and lateral margins interrupted by a slight anteromedial angulation. In palpebral view, anterior third of axial furrows diverge at about $30^{\circ}$ to the exsagittal direction, but do not reach the anterior margin, even in the more clearly impressed internal mould. Anterior pit absent. Muscle impressions weakly marked, especially on external mould. Occipital muscle impression adjacent to axial furrow, exsagittally half as long
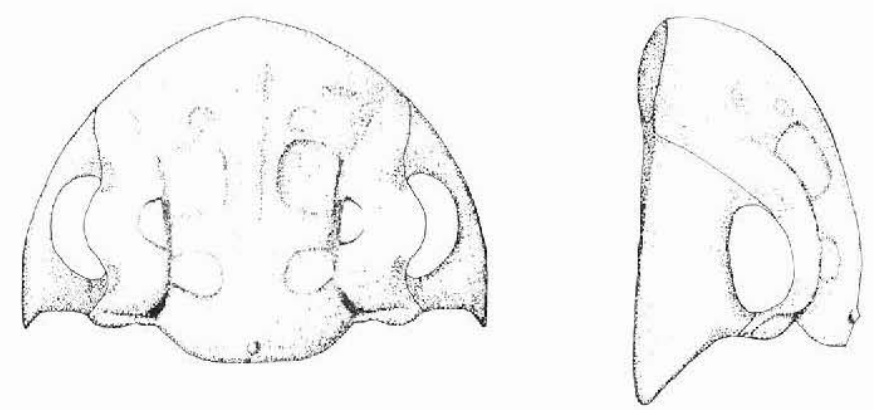

Fig. 3. Reconstruction of cephalon and pygidium of Ligiscus arcanus gen. et sp. nov., about $\times 4$.

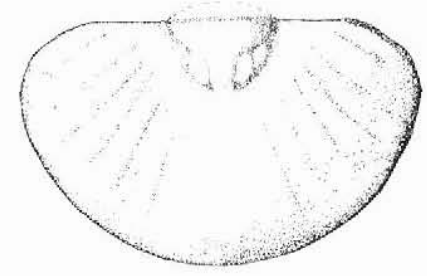

as visual surface, two-thirds as long as wide, and reaching about one-quarter way across glabella, its posterior margin a little less than its own exsagittal length from the posterior margin of the glabella. Lateral muscle impression less than a semicircle on the fixed cheek, as long (exs.) as occipital impression and with its posterior margin on the same transverse line as the anterior margin of the occipital impression. $1 \mathrm{G}$ subquadrate, adjacent to axial furrow, the largest impression, posteriorly overlapping with the anterior half of the lateral muscle impression, two-thirds as wide (tr.) as long (exs.), reaching a little over one-quarter 
way across glabella. $2 \mathrm{G}$ small, ovate, longer than wide (tr.) placed adjacent to the anterior adaxial corner of $1 \mathrm{G}$, but with its inner margin farther from the sagittal line. $3 \mathrm{G}$ smallest, transversely elongate, placed at about its own width (tr.) from the point where the axial furrow becomes effaced. Anterior section of facial suture almost straight but with slight sigmoid curve, running forward at a low angle to the exsagittal direction so that it approaches the axial furrow; posterior section runs at a small angle to the exsagittal direction out and back, with slight sigmoid curvature. Visual surface of eye about one-third sagittal length of cranidium, placed at about half its own length (exc.) from the posterior margin; lenses apparently holochroal, arranged in about 35-40 files with a maximum of 10 lenses per file. Free cheek convex, produced into a stout short genal spine. Palpebral lobe horizontal, reaching a height a little less than the maximum height of the glabella at that transverse line. Glabella (except muscle impressions, anterior part of fixed cheek and free cheek) with terrace 'ridges' which at the anterior of the glabella have the steep slope facing posteriorly; on the glabella, these ridges rarely anastomose, though they more commonly do on the free cheek. On fixed cheek adaxial to the palpebral lobe, the external mould lacks sculpture but the internal mould has fairly closely packed small granules, each one-third to one-quarter the diameter of the glabellar tubercle.

Rostral plate with its curved anterior margin parallel to that of cranidium. Lateral angles sharp; posteromedially is a raised platform. About 9 terrace 'ridges' are placed subparallel to each other and the anterior margin. Hypostome unknown.

Pygidium (known only from an incomplete, mainly internal mould) convex, three-fifths as long as wide (tr.) in dorsal view. Axis a little over one-third sagittal length in this view, pentagonal in outline, its posterior half transversely trilobed. Pleural field with 5 furrows and ribs discernible, behind this effaced. Exoskeleton present indicates the extreme indistinctness of at least abaxial parts of ribs and furrows.

Discussion. L. arcanus is another of those effaced trilobites seemingly showing a preference for rocks of carbonate mound facies. In addition to this record in Washington Land, a congeneric and possible conspecific form has been observed by P.D.L. in a preliminary examination of collections made in carbonate mound facies in Peary Land, Valdemar Glückstadt Land and Kronprins Christian Land in more easterly areas of North Greenland. Although it is likely that these latter occurrences are in rocks of very similar age to those described here, such forms can probably not be used for detailed biostratigraphic correlation since they form part of a strongly environmentally controlled association of animals.

The morphology of trilobites of this general type has been taken to indicate a shallow burrowing mode of life since by orienting the long axis of the visual field parallel and near to the sediment surface, the thorax and pygidium extend down and back, and thus lay in the sediment (Finch, 1904; Bergström, 1973). The particular advantages of an effaced morphology to this mode of life are not immediately evident, except for the obvious one of ease of inserting the smooth, streamlined pygidium into the sediment by backwards burrowing. The effacement and convexity of the cephalon are not, however, accounted for by such a process. One common consequence of effacement in the cephalon and pygidium is the loss of apodemes in favour of areas, sometimes quite large, on the ventral surface of the dorsal exoskeleton, to which muscles were probably attached. It is not impossible that these increased areas of attachment were for large muscles providing an advantage in the burrowing process. 


\section{Family Proetidae Salter, 1864 \\ Subfamily Proetinae Salter, 1864 \\ Genus Xenocybe Owens, 1973a}

Synonym. Trigonoproetus Appolonov, 1974.

Type species. By original designation; Xenocybe micrommata Owens 1973a, from Ordovician, Ashgill Series, Rawtheyan Stage, 5a, Holmenskjaeret, Oslo district, Norway.

Diagnosis. Proetine with incised $1 \mathrm{~S}$ and 2S, preglabellar field, pygidium with 9 axial rings, and 7 pairs of pleural ribs and narrow border; hypostome narrow, elongated, with rounded posterior margin without spines; sculpture granulose or with a combination of striations and granules.

Remarks. Xenocybe has hitherto been known only from rare cephalic remains from the late Ashgill of Norway (Owens, 1973a), Kazakhstan (Appolonov, 1974) and North East Siberia (Chugaeva, 1975). The place of the genus in the Proetidae has remained uncertain because of the incomplete information available. The abundant and well preserved material from Washington Land includes all exoskeletal parts, with some almost complete specimens (lacking only free cheeks). This now makes it possible to confidently assign the genus to the Proetinae since, although the cephalon has a combination of features which might be regarded as atypical for the subfamily (e.g., the incised $1 \mathrm{~S}$ and $2 \mathrm{~S}$ and preglabellar field), the thorax with 10 segments with the preannulus and the structure of the pygidium (particularly of the pleural ribs) are typical proetine characters.

The known record of the Proetinae extends back to the early Caradoc, where species of Proetus and Cyphoproetus occur (Tripp, 1954, 1980). In the Ashgill, species of Proetus (s.l.), Cyphoproetus and Ascetopeltis are present (Owens, 1973a, 1973b; McNamara, 1979). Of these, it appears most likely that Xenocybe has its origins in Proetus (s.1.). Proetus (s.l.) ainae Warburg, 1925 (Owens, 1973a, fig. 1A-F, H-L) has a short preglabellar field, conical glabella and a pygidium whose general appearance (particularly internal moulds, cf. Owens, 1973a, fig. 1I and Plate 3, fig. 1 herein) is very similar to that of $X$. ebyconex sp. nov. The deepening of the lateral glabellar furrows of a species such as $P$. (s.l.) ainae could produce a very similar appearance to Xenocybe.

Of Llandovery and Wenlock proetines, Schizoproetus delicatus (Hedström, 1923, pl. 1, figs 1-15) and $S$. aff. $S$. delicatus (Hedström, 1923) of Owens $(1973 \mathrm{~b}$, pl. 15, figs 16, 17) from the upper Wenlock of Gotland and Dudley respectively are similar to Xenocybe in general aspect. Owens (1973b, p. 37) assigned these species to Schizoproetus, whose type species occurs in the Middle Devonian, but this assignment is no longer regarded tenable. Instead, they appear to belong to Dechenellurus Maximova, 1960 or a closely related genus. The origins of these species have remained uncertain, but it is likely that they lie in the group of proetines which includes $X$ enocybe.

It is interesting to note that the broad morphology of Xenocybe is repeated in a number of Upper Palaeozoic proetids which inhabitated a similar carbonate mound evironment. Examples include Denemarkia frontalis (Hawle \& Corda, 1847) (see Šnajdr, 1980, pl. 27, figs 1-14) from the Lower Devonian Upper Koněprusy Limestone, Prague district, Czechoslovakia, Phillibolina worsawensis (Osmólska, 1968, pl. 3, fig. 8; pl. 6, fig. 5) from 
the Carboniferous (Dinantian), Clitheroe district, northern England and Piltonia kuehnei Hahn, 1964 (Osmólska, 1970, pl. 9, fig. 9) from the Carboniferous (Dinantian), Tournai, Belgium. None of these belong to the Proetinae, but they show that several independent proetid groups responded in a similar way to similar environments.

\section{Xenocybe ebyconex sp. nov.}

Plate 2, figs 1-11; Plate 3, figs 1, 2; Fig. 4

Figured material. Holotype. MGUH 15.372 cephalon with parts of six thoracic segments. Paratypes. MGUH 15.373 (complete specimen lacking free cheeks); MGUH 15.374 (cephalon); MGUH 15.375 (cranidium); MGUH 15.376,7 (free cheeks); MGUH 15.378 (hypostome); MGUH 15.379 (thoracic segments); MGUH 15.380,81 (pygidia with attached thoracic segments); MGUH 15.383-4 (pygidia).

Other material. See Table 1.

Diagnosis. Xenocybe with very short (sag.) preglabellar field, inflated area at posterolateral corner of free cheek, weakly developed lateral occipital lobes, and granulose sculpture.

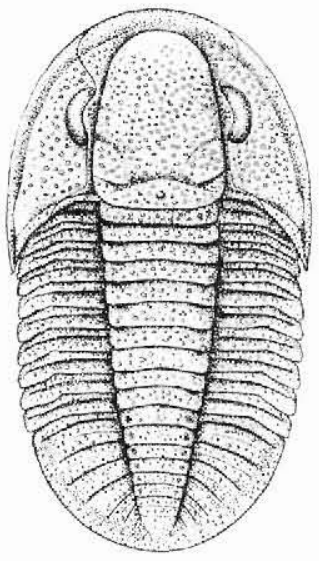

Fig. 4. Reconstruction of Xenocybe ebyconex sp. nov., about $\times 3$.

Description. Cephalon with rather narrow, convex border, defined by deep, broad anterior and lateral border furrows. Glabella with gentle forward taper, rounded frontal lobe sloping steeply downwards, marginally longer (sag.) than wide (tr.). $1 \mathrm{~S}$ and $2 \mathrm{~S}$ incised, confluent with axial furrow. 1S meets axial furrow about one-quarter way forward from posterior end of glabella, opposite $\varepsilon$, curving backwards and shallowing before it runs into occipital furrow. Resultant 1L subquadrate in outline. Small, anterior branch of $1 \mathrm{~S}$ is seen on most specimens as a smooth area interrupting the granular sculpture, but is incised on some (e.g., Plate 2, fig. 2). $2 \mathrm{~S}$ shallower and shorter than $1 \mathrm{~S}$, situated about half-way along glabella and directed backwards at about $30^{\circ}$ to a transverse line through its abaxial end. $2 \mathrm{~L}$ about as long (exs.) as 1L. 3S not visible on most specimens, but seen on some (e.g., Plate 2, fig. 1) as a small inconspicuous smooth area opposite and isolated from axial furrow.

Occipital furrow arched forwards sagittally and again laterally so that its most posterior parts are behind the adaxial ends of $1 \mathrm{~L}$. Here it shallows and broadens where anteriorly it is 
joined by $1 \mathrm{~S}$ and posteriorly by furrow which partially defines lateral occipital lobe. This latter furrow dies out before reaching axial furrow. Occipital ring marginally wider (tr.) than glabella, narrowing laterally behind $1 \mathrm{~L}$. Small median node present.

Preglabellar field short, as long (sag.) as anterior border (Plate 2, fig. 1b) on larger specimens, but proportionately longer on smaller specimens (Plate 2, fig. 3). On larger specimens it is hardly apparent in dorsal view (Plate 2, fig. 1a) because it is overhung by frontal lobe of glabella; it can be seen clearly on smaller specimens (Plate 2, figs 2, 3, 7). Preocular facial sutures divergent, extending farther abaxially than palpebral lobe. Postocular facial sutures with $\varepsilon$ and $\zeta$ widely separated, the intervening stretch running close to and parallel with axial furrow. At $\zeta$ postocular suture turns abruptly abaxially so as to incorporate narrow band of posterior cephalic border onto postocular fixed cheek.

Palpebral lobe a little under one-third length (sag.) of glabella, situated about half-way along glabella plus occipital ring with $\gamma$ and $\varepsilon$ close to axial furrow. Eye reniform, a little over one-third length (sag.) of glabella, situated on a narrow eye socle (Plate 2, figs $1 \mathrm{~b}, 8$ ) which broadens at both ends. Field of free cheek steeply declined so that it appears narrow in dorsal view (Plate 2, fig. 1a; cf. with Plate 2, figs 1b, 5, 6). Posterolateral corner of free cheek inflated (e.g., Plate 2, figs 1a, 5, 8); inflated area does not represent thickening of cuticle, since it is to be seen on internal moulds. Posterior border furrow narrow and deep, meeting lateral at base of short genal spine, which has a prominent median groove.

Cephalic doublure ventrally convex (Plate 2, fig. 5), corresponding in width to border and with 4 or 5 prominent raised terrace ridges. Left hand connective suture (Plate 5, fig. 5) shows that they are backwardly convergent, with rostral plate (not seen) either trapezoidal or triangular. Hypostome elongated, narrow anterior margin curved gently forwards, anterior border furrow broad, shallowing laterally at base of strongly upturned anterior wing. Lateral border furrow also shallows at base of anterior wing, but posterior from here is deep and broad, defining a narrow lateral border. Lateral margins backwardly convergent as far as point opposite median furrow, where it curves abaxially before converging once again around rounded posterior end of hypostome. Posterior border broader than lateral and flattened. Median body moderately convex, divided into a long anterior and short posterior lobe by short, shallow backwardly directed median furrows.

Thorax of ten segments, the axis tapering gently backwards so that last ring is about two-thirds width (tr.) of first. Axis a little wider (tr.) than pleurae anteriorly, but approximately same width posteriorly. Axial rings with a narrow (sag.) preannulus (Plate 2, fig. 11), separated from articulating half ring by deep articulating furrow. Pleura with broad, deep pleural furrow extending close to abaxial end where it narrows and is truncated by posterior edge of articulating facet. Posterior pleural band a little wider (exs.) than anterior. Abaxial end of pleura bluntly truncated.

Pygidium subparabolic in large specimens (e.g., Plate 2, fig. 6), but proportionately wider and shorter in smaller ones (e.g., Plate 2, figs 9, 10), with narrow, flattened border. Axis narrower than pleural areas anteriorly, extending almost to inner edge of border, where its posterior end is ill-defined, and tapers backwards so that axial furrows enclose an angle of about $20^{\circ}$. Nine axial rings clearly defined by nearly transverse ring furrows. Pleural areas with seven pairs of pleural ribs which curve very gently backwards from axial furrow. Pleural furrows deep, truncated at inner edge of border, interpleural furrows narrow and shallow, also truncated at inner edge of border. Anterior and posterior pleural bands of approximately equal width (exs.). 
Entire dorsal exoskeleton has sculpture of granules, which are coarser on axial areas and field of free cheeks and pleural areas of larger specimens. These granules are interspersed with finer ones which occur also on the cephalic border, pleural areas of the thorax and pygidium and also in the cephalic border furrow, occipital ring (Plate 2, figs 1a, b) thoracic and pygidial pleural furrows (Plate 2, fig. 1a; Plate 3, fig. 2). On smaller specimens, (e.g., Plate 2, figs $3,7,9,10$ ) the granulation is proportionately coarser over the entire dorsal exoskeleton.

Remarks. X. ebyconex is readily distinguished from the Ashgill species by its short preglabellar field, lateral occipital lobes, inflated postero-lateral corners of free cheeks and granulose sculpture.

\section{Family Harpedidae Hawle \& Corda, 1847}

Discussion. Following the argument presented by Fortey $(1980$, p. 76) we prefer to use the above form of the family-group name as a translation by Salter (1864) of Harpides Hawle \& Corda, 1847.

\section{Genus Scotoharpes Lamont, 1948}

Type species. By monotypy; Scotoharpes domina Lamont, 1948 from the Upper Llandovery of Lothian, Scotland.

Diagnosis. See Norford (1973, p. 11).

\section{Scotoharpes sp.}

Plate 5, fig. 5

Figured material. MGUH 15.385 (fringe prolongation).

Discussion. A single fragment of fringe can be referred to Scotoharpes. Its shape, and the density and style of pitting indicate that it is close to $S$. loma (Lane, 1972), although in the absence of more complete material a definite assignment cannot be made.

\section{Family Cheiruridae Hawle \& Corda, 1847 \\ Subfamily Sphaerexochinae Öpik, 1937}

Discussion. The emended diagnosis by Thomas (1981, p. 61) of this subfamily has been modified because of the observations made below in the discussion of Hyrokybe meliceris sp. nov. The genus is shown to have the three pairs of lateral glabellar furrows typical of previously described members of the subfamily. Additionally, we now regard it unreasonable to separate the Sphaerexochinae and the Acanthoparyphinae, and the arguments for this are presented in the same discussion below.

Diagnosis. Glabella inflated, often dominating the cephalon, with three pairs of lateral furrows. Palpebral lobe placed close to axial furrow. Free cheek small, almost vertical. 
Hypostome wider than long; anterior and posterior lobes of middle body of similar length; posterior margin indented. Thorax of ten to twelve segments with unfurrowed pleurae. Pygidium with two or three pairs of completely or partly fused pleural spines.

\section{Genus Sphaerexochus Beyrich, 1845}

Type species. By monotypy; Sphaerexochus mirus Beyrich, 1845, originally described from the Wenlock of Czechoslovakia.

Remarks. For list of included species, diagnosis and discussion of this genus see Lane (1971, p. 53) and Thomas (1981, p. 61).

\section{Sphaerexochus centeo sp. nov.}

Plate 4, figs 1-10, 12-15; ?11

Derivation of name. Greek, 'kenteo', a spur, referring to the pygidial spines.

Figured material. Holotype, MGUH 15.386 (pygidium). Paratypes, MGUH 15.387 (cephalon); MGUH 15.388-92 (cranidia); MGUH 15.393-5 (hypostomes); MGUH 15.396,7 (thoracic segments); MGUH 15.398,9 (pygidia).

Other material. See Table 1.

Diagnosis. Sphaerexochus species with weakly developed $2 \mathrm{~S}$ and $3 \mathrm{~S}$, glabella with keel developed on internal mould; pygidium with three pairs of relatively long, terminally hooked, radially disposed spines.

Description. Cephalon one-half wider (tr.) than long (sag.), dominated by inflated subspherical glabella which in dorsal view is one-fifth wider (tr.) than long (sag.). Occipital, axial, border an $1 \mathrm{~S}$ furrows wide and deep. 1L unevenly curved in outline, greatest curvature between short almost straight adaxial margin and the straight to weakly concave anterior margin; outline evenly curved laterally and posteriorly. As a result of this outline, 1S curves sharply back in its course through a little over a right angle, isolating $1 \mathrm{~L}$, which is only slightly independently inflated. $2 \mathrm{~S}$ and $3 \mathrm{~S}$ parallel, barely incised, except adjacent to axial furrow on the internal mould where they kink sharply backwards. On external mould these furrows appear as narrow zones of interruption of the finely granulate sculpture both reaching about one-quarter the length of the arc (tr.) at its respective position. 3L longer (exs.) than $2 \mathrm{~L}$, both shorter than $1 \mathrm{~L}$. Median glabellar lobe with slightly convergent lateral margins behind, anteriorly the internal mould shows a weak sagittal keel. Anterior section of facial suture slightly sigmoidally curved subparallel to the axial furrow. Palpebral lobe close to axial furrow, extending from opposite anterior of $2 \mathrm{~L}$ to the anterior of $1 \mathrm{~L}$. Posterior section of facial suture curving strongly back from posterior of palpebral lobe, then running straight back at about $45^{\circ}$ to transverse direction across outer part of field of fixed cheek, lateral border furrow and lateral border, but again curving strongly back across outer part of border. Field of fixed and free cheeks with a few large randomly scattered, shallow, flat-bottomed pits. 
Hypostome about half as wide (tr.) again as long (sag.) although there is some variation in overall proportions (cf. Plate 4, figs 7, 9). Anterior margin almost transverse; middle body convex, subquadrate with maculae defined; posterior border least convex, with a sagittal invagination in the posterior margin.

Number of thoracic segments unknown, in form typical of the genus.

Pygidium including spines three-quarters as long (exs.) as wide (tr.). Axis with two anterior rings of the form of the thoracic axial rings, and a third ring only demarcated laterally; terminal piece rounded-triangular, longer (sag.) than wide at its widest point (anteriorly). Interring furrows distinct and much wider than axial furrow. Three pleural ribs end in relatively long terminal backwardly hooked spines. Doublure wide, posteriorly underlying about half the length of the terminal piece of the axis.

Whole exoskeleton finely granulose.

Discussion. Thomas (1981, p. 62) has discussed Silurian species of the genus, and S. centeo is immediately distinguishable from all those mentioned by its longer pygidial spines. In general morphology, $S$. centeo most closely resembles $S$. laciniatus Lindström, 1885, from which it also differs in possessing longer pygidial spines.

A hypostome (MGUH 15.400, Plate 4, fig. 11) is referred to this species with some doubt. It is relatively much longer than those referred without doubt, with a relatively much wider posterior border furrow, and lacks the posterior marginal invagination.

\section{Genus Hyrokybe Lane, 1972}

Type species. By original designation; H. pharanx Lane, 1972, from the upper Llandovery or lower Wenlock of Kronprins Christian Land, eastern North Greenland.

Diagnosis. For the reasons given below in the discussion of $H$. meliceris Lane's (1972, p. 358) diagnosis has been emended, since a $3 S$ lateral glabellar furrow is present; it should include the statement that the $1 \mathrm{~L}$ lobe is not isolated and has but little, if any, independent inflation.

\section{Hyrokybe meliceris sp. nov. \\ Plate 5, figs 1, 3}

Derivation of name. Greek, 'skin eruption', referring to the coarse sculpture.

Figured material. Holotype MGUH 15.401 (cephalon). Paratype MGUH 15.402 (cephalon).

Other material. See Table 1.

Diagnosis. Hyrokybe with equally distinct $2 \mathrm{~S}$ and $3 \mathrm{~S}$ furrows, and sculpture of coarse, closely packed granules.

Description. Cephalon greatly inflated, dominated by subhemispherical glabella; cheeks small, pendent. $3 \mathrm{~S}$ about one-sixth and $2 \mathrm{~S}$ about one-quarter length of glabellar transverse profile at their respective levels, both failing to reach axial furrow by a small amount. $3 \mathrm{~S}$ 
strongly curved concave forwards abaxially, where it is close to the confluence of lateral border, axial and preglabellar furrows. $2 \mathrm{~S}$ gently curved convex forwards. $3 \mathrm{~L}$ and $2 \mathrm{~L}$ of about the same exsagittal length. $1 \mathrm{~S}$ curved convex forwards from axial furrow to about one-third way across glabella, never reaching the occipital furrow although in smaller specimens it continues exsagittally back for a distance as a weak concavity. Eye small, visual surface about half as long as $2 \mathrm{~L}$ (exs.) its mid-point opposite posterior part of $2 \mathrm{~L}$. Visual surface, which is inflated, subcircular in outline, separate lenses visible with about 15 files with 12 lenses maximum in each, the whole surrounded by an annular convex ridge formed of the socle and palpebral ridge. Posterior section of facial suture curves strongly back towards postero-lateral corner of cheek. Lateral border and border furrows distinct and narrow. Whole surface covered with large closely packed imperforate tubercles.

Rostral plate very short (sag. and exs.) and wide. Hypostome subquadrate with narrow border and border furrows, nearly twice as wide (tr.) as long. Middle body with posterior lobe a little less than half the length of the whole. Sculpture similar to dorsal surface of cephalon.

Discussion. The generic placement of this form has required a reconsideration of the Sphaerexochinae and Acanthoparyphinae and some of their contained genera.

Amongst the features said to be diagnostic of Hyrokybe erected and referred to the Sphaerexochinae by Lane $(1972$, p. 358$)$ was the lack of $3 S$. Re-examination of H. pharanx, however, shows that in some specimens an exceedingly weak linear transverse feature on the exoskeleton lies remote from the axial furrow in the position of the $3 \mathrm{~S}$ of $H$. meliceris, i.e., adjacent to the confluence of lateral border, axial and preglabellar furrows. Further, preparation has revealed a somewhat stronger feature in this position on the internal mould. In any case, it now appears to us that the loss of a $3 \mathrm{~S}$ furrow in such a morphologically diverse group as the Cheiruridae should not, alone, be considered a character of generic importance.

The features by which Hyrokybe species can be most easily distinguished from Sphaerexochus are the coarse granulation and, particularly, the form of 1S. Sphaerexochus comprises a closely-knit group of species ranging in age from Arenig to Ludlow, in which $1 \mathrm{~S}$ is always strongly developed and isolates $1 \mathrm{~L}$, which itself is usually independently inflated. Hyrokybe then differs in its non-isolated $1 \mathrm{~L}$ which in any case lacks independent inflation. Other than these features, and the coarse sculpture, the morphology of Hyrokybe is very close to Sphaerexochus, even to the similarity in the form and disposition of the hypostome (compare S. pulcher Whittington \& Evitt, 1954, text-fig. 25, with Plate 5, fig. 3a).

Amongst cheirurids, coarse sculpture, linked with general inflation of the exoskeleton are characters, amongst others, typical of genera referred to the Acanthoparyphinae. Youngia, for instance, displays these characters, and in forms referred to this genus, has a completely or incompletely isolated $1 \mathrm{~L}$, e.g., Y. trispinosa and $Y$. aff. $Y$. trispinosa (compare Lane, 1971, pl. 16, figs 1-4, 7-9, 11, 13 with Lane, 1971, pl. 16, fig. 10). Species of other, perhaps better-known acanthoparyphine genera (e.g., Acanthoparypha Whittington \& Evitt, 1954, the possibly synonymous Pandaspinapyga Esker \& Levin, 1964, and Holia Bradley, 1930) have inflated tuberculate or spiny exoskeletons, and non-isolated 1L lobes. Pompeckia Warburg, 1925, referred to the Sphaerexochinae, also has non-isolated basal glabellar lobes.

The major difference, therefore, between the Sphaerexochinae and the Acanthoparyphinae as presently recognized, seems to be in the pygidium in which there are three pairs of free or fused spines in the former subfamily, and two in the latter. As has been 
shown elsewhere (Lane, 1971, p. 72) the number of free spines in the cheirurid pygidium may vary, even within genera, dependant upon two processes:

1) Spines may be 'added' to the pygidium by failure to release from the 'transitory pygidium' in ontogeny, giving a 'segment' of the form of a thoracic segment at the anterior of the pygidium (e.g., Deiphon Barrande, 1850, Sphaerocoryphe Angelin, 1954 and probably Crotalocephalina Přibyl \& Vaněk, 1964).

2) Spines may be lost posteriorly by simple decrease in size and ultimately failure to develop.

Consequently, we consider that the use of a single character ( 2 pairs of free spines in the pygidium) to delimit the Acanthoparyphinae to be unsatisfactory.

Ignoring tuberculation or spiny sculpture, the overall form of Sphaerexochus spp., $H$. pharanx, H. meliceris, Youngia spp. and Pompeckia spp. are so similar that subfamilial separation seems unreasonable. Consequently the two subfamilies are synonymized. This immediately solves the problem of placing species of Pompeckia which have an 'acanthoparyphine' cephalon (non-isolated 1L) and sphaerexochine pygidium (three pairs of free spines).

Although beyond the scope of this discussion, the placement of certain genera at present referred to the Deiphoninae and Eccoptochilinae, and the status of these subfamilies as natural groups, may be questioned on similar lines.

The Sphaerexochinae as now conceived consists of a morphologically diverse but phyletically closely-linked group of cheirurids with general inflation of the exoskeleton, and often a coarsely granulate and spiny sculpture.

Family Lichidae Hawle \& Corda, 1847

Subfamily Ceratarginae Tripp, 1957

Genus Dicranogmus Hawle \& Corda, 1847

Type species. By original designation; Dicranogmus pustulatus Hawle \& Corda, 1847 (= Lichas simplex Barrande, 1846) from the Budñany Limestone (Late Silurian) of Czechoslovakia.

\section{Dicranogmus? sp.}

Plate 5, figs 4, 6, 7

?1972 Dicranopeltis? sp.; Lane, p. 360, pl. 64, figs 5, 8.

1980 cf. Platylichas sp.; Lane in Hurst, p. 33.

Figured material. MGUH 15.403 (cephalon); MGUH 15.404 (hypostome); MGUH 15.405 (pygidium).

Other material. See Table 1.

Description. Cephalon convex, dominated by subhemispherical glabella. With the exception of the preglabellar and occipital furrows, glabellar furrows largely effaced, although faint longitudinal glabellar furrows can be seen. Cheeks largely pendent with distinct posterior border and border furrow and less distinct lateral border and border furrow. Eyes large, convex and prominent. Genal spines very short. Sculpture everywhere of large to small 
closely packed granules which contribute to the difficulty of recognizing furrows; granules generally becoming smaller and less distinct anteriorly on the glabella.

Referred hypostome incompletely preserved, with clearly marked indentation of more than 50 per cent of the posterior margin. The whole plate wider than long. Posterior border very wide, lateral border narrower than this. Middle body twice as wide as long, with middle furrow placed two-thirds way back, and only distinct laterally.

Pygidium semicircular, half as wide again as long. Axis anteriorly more than one-third of the width of the whole, reaching two-thirds way back, indistinctly demarcated behind; bearing one clear anterior axial ring and furrow and, indistinctly one or two farther to the rear. Coarse to fine granules on axis and pleural fields (like that of cephalon) largely obscure other furrows, although a furrowed anterior pleural rib and one (?two) wider, possibly furrowed pleural ribs lie behind. Nature of margin not clear, but lacking large spines and with three tiny indentations at each side adjacent to the interpleural rib furrows.

Discussion. The problem of generic placement of lichid material is well known, but it is preferred to refer this material and, now, that described by Lane (1972) to Dicranogmus. It is thought that the great convexity and effacement of the glabellar furrows are not consistent with a position in Dicranopeltis. Additionally, the pygidium referred to this form (since the sculpture is identical to that of the cephalon), is unlike that of Dicranopeltis in its semicircular outline, short, wide axis and probable very short marginal spines. This pygidium is possibly the first described in Dicranogmus.

Of the material described from Kronprins Christian Land (Lane, 1972) the incomplete cephalon (pl. 64, figs 5a-c) is exceedingly similar to the Washington Land material. The figured cranidium (Lane, 1972, pl. 64, figs 8a-d) differs only in the less obscure and less effaced furrows.

\section{Family Odontopleuridae Burmeister, 1843 \\ Subfamily Miraspidinae Richter \& Richter, 1917 Genus Ceratocephala Warder, 1838}

Type species. By monotypy (see Thomas, 1981, p. 93); Ceratocephala goniata Warder, 1838, p. 378, unnumbered text-fig.; from the middle Silurian of Springfield, Ohio.

Diagnosis. See Thomas (1981, p. 93).

Ceratocephala cf. C. bicuspis Angelin, 1854

Plate 5, figs 8, 9

Figured material. MGUH 15.406,7 (cephala).

Other material. See Table 1.

Discussion. The available material of this form is incompletely preserved and one of the cephala is very small. However, they show most similarity to the single specimen described by Angelin (see Bruton, 1967, p. 241, pl. 36, fig. 11). In addition to the similarity of the 
general proportions, the widening of the median lobe of the glabella and the presence of an exceedingly small $3 \mathrm{~L}$ are notable. Sculpture is also similar.

The free cheek described by Lane (1972, p. 361, pl. 64, figs 4a, b) from the upper Llandovery or lower Wenlock of Kronprins Christian Land, eastern North Greenland appears to agree in all respects with that described here. Particularly notable is the flat-topped lateral border with double row of tubercles seen in both forms.

C. bicuspis is only known from the Wenlock (probably Högklint Beds of Lower Wenlock age) of Gotland, Sweden.

\section{?trilobite fragment}

Plate 5, fig. 2

Figured material. MGUH 15.408.

Discussion. The small, flask-shaped object figured is preserved in a way entirely like that of the trilobites described above. As oriented on the plate it has the appearance of a very narrow middle body of a hypostome. Inverted, it is not unlike an encrinurid hypostome in outline. The polygonal ridge-pattern which forms the sculpture is most similar, amongst trilobites of similar age, to that of Opoa adamsi Lane, 1972 from Kronprins Christian Land. This genus is not, however, represented in these collections.

Acknowledgements. We thank A. T. Thomas and Y. Howells who improved the whole manuscript.

\section{References}

Angelin, N. P. 1854: Palaeontologia Scandinavica. I. Crustacea formationis transitionis. 2, 21-92. Appolonov, M. K. 1974: Ashgill'skie trilobity Kazakhstana. Akad. Nauk. Kaz. SSR. 136 pp.

Barrande, J. 1846: Notice préliminaire sur le Système Silurien et les trilobites de Bohême. 97 pp. Leipsic. Barrande, J. 1850: (Bohemian trilobites). Ber. Mitt. Freunden naturw. Wien, 7, 4-7.

Bassler, R. S. 1915: Bibliographic index of American Ordovician and Silurian fossils. Vol. 1. Bull. U.S. Natl Mus. 92, viii + 719 pp.

Bergström, J. 1973: Organization, life and systematics of trilobites. Fossils and Strata 2, 69 pp.

Beyrich, E. 1845: Ueber einige böhmischen Trilobiten, 47 pp. Berlin.

Bradley, J. H. 1930: Fauna of the Kimmswick Limestone of Missouri and Illinois. Contr. Walker Mus. 2,(6), 219-290.

Bruton, D. L. 1967: Silurian odontopleurid trilobites from Sweden, Estonia, and Latvia. Palaeontology 10, 214-244.

Burmeister, H. 1843: Die Organisation der Trilobiten, aus ihren lebenden Verwandten entwickelt; nebst einer systematischen Ubersicht aller zeither beschreibenen Arten, $147 \mathrm{pp}$. Berlin.

Chugaeva, M. N. 1975: Trilobity pozdnego Ordovika severo-vostoka SSSR. Trudy geol. Inst. Moscow 272, 76 pp.

Esker, G. C. \& Levin, H. 1964: Pandaspinapyga, a new trilobite genus from the Kimmswick Limestone (Ordovician) of Missouri. J. Paleont. 38, 776-8.

Finch, G. E. 1904: Notes on the position of the individuals in a group of Nileus vigilans found at Elgin, Iowa. Proc. Iowa Acad. Sci. 11, 178-181.

Fortey, R. A. 1974: A new pelagic trilobite from the Ordovician of Spitsbergen, Ireland and Utah. Palaeontology 17, 111-124. 
Fortey, R. A. 1980: Generic longevity in Lower Ordovician trilobites: relation to environment. Paleobiology 6, 24-31.

Hahn, G. 1964: Trilobiten der unteren Pericyclus-Stufe (Unterkarbon) aus dem Kohlenkalk Belgiens. 2. Morphologie, Variabilität und postlarvale Ontogenie von Brachymetopus maccoyi spinosus Hahn 1964 und von Piltonia kuehnei n. sp. Senckenb. Leth. 45, 347-379.

Hawle, I. \& Corda, A. J. C. 1847: Prodrom einer Monographie der böhmischen Trilobiten. Abh. K. böhm. Ges. Wiss. 176 pp.

Hedström, H. 1923: Contributions to the fossil fauna of Gotland. I. Sver. geol. Unders. Afh. C, 316, $1-24$.

Hornỳ, R. \& Bastl, F. 1970: Type specimens of fossils in the National Museum, Prague, Volume 1. Trilobita, 354 pp. Prague: National Museum.

Hurst, J. M. 1980: Silurian stratigraphy and facies distribution in Washington Land and western Hall Land, North Greenland. Bull. Grønlands geol. Unders. 138, 95 pp.

Lamont, A. 1948: Scottish dragons. Quarry Managers' J. 31, 531-535.

Lane, P. D. 1971: British Cheiruridae (Trilobita). Monogr. Palaeontogr. Soc, 95 pp. London.

Lane, P. D. 1972: New trilobites from the Silurian of north-east Greenland, with a note on trilobite faunas in pure limestones. Palaeontology 15, 336-364.

Lane, P. D. 1979: Llandovery trilobites from Washington Land, North Greenland. Bull. Grønlands geol. Unders. 131, $37 \mathrm{pp}$.

Lane, P. D. 1980: Monoceratella (Ostracoda) from the Silurian of Washington Land, North Greenland. Rapp. Grønlands geol. Unders. 101, 37-43.

Lindström, G. 1885: Förteckning på Gotlands siluriska crustaceer. Öfvers. K. VetenskAkad. Förh. 6, 37-100.

Lowenstam, H. A. 1957: Niagaran reefs in the Great Lakes Area. Mem. geol. Soc. Amer. 67, 215-248.

Maximova, Z. A. 1960: [New Middle Palaeozoic trilobites of central Kazakhstan, Rudny Altae and the Arctic]. In Markovsky, B. P. (edit.). New species of prehistoric plants and invertebrates of the USSR. Part 2. VSEGEI, 256-280.

McNamara, K. J. 1979: Trilobites from the Coniston Limestone Group (Ashgill Series) of the Lake District, England. Palaeontology 22, 53-92.

Mikulic, D. G. 1981: Trilobites in Paleozoic carbonate buildups. Lethaia, 14, 45-56.

Murchison, R. I. 1839: The Silurian System, 768 pp. London.

Norford, B. S. 1972: Silurian stratigraphic sections at Kap Tyson, Offley $\varnothing$ and Kap Schuchert, Northwestern Greenland. Meddr Grønland 195(2), 40 pp.

Norford, B. S. 1973: Lower Silurian species of the trilobite Scotoharpes from Canada and northwestern Greenland. Bull. geol. Surv. Canada 222, 8-32.

Norford, B. S. 1981: The trilobite fauna of the Silurian Attawapiskat Formation, northern Ontario and northern Manitoba. Bull. geol. Surv. Canada 327, 1-36.

Öpik, A. A. 1937: Trilobiten aus Estland. Acta Comment. Univ. Tartu (A), 32, 1-163.

Osmólska, H. 1968: Contributions to the Lower Carboniferous Cyrtosymbolinae (Trilobita). Acta palaeont. pol. 13, 119-150.

Osmólska, H. 1970: Revision of non-cyrtosymbolinid trilobites from the Tournaisian-Namurian of Eurasia. Palaeont. pol. 23, 165 pp.

Owens, R. M. 1973a: Ordovician Proetidae (Trilobita) from Scandinavia. Norsk geol. Tidsskr. 53, 117-181.

Owens, R. M. 1973b: British Ordovician and Silurian Proetidae (Trilobita). Monogr. Palaeontogr. Soc., $98 \mathrm{pp}$.

Přibyl, A. \& Vaněk, J. 1964: Několik poznámek ke klasifikaci rodu Cheirurus Beyrich (Trilobita). Čas. národ. Muz. 133,(2), 93-95.

Richter, R. \& Richter, E. 1917: Über die Einteilung der Familie Acidaspidae und über einige ihrer devonischen Vertreter. Centbl. Miner. Geol. Palaeont. 1917, 462-472. 
Richter, R. \& Richter, E. 1925: Unterlagen zum Fossilium Catalogus. Trilobitae. III. Senckenbergiana 7, 239-244.

Salter, J. W. 1864: A monograph of the British trilobites from the Cambrian, Silurian and Devonian formations. Part 1. Monogr. Palaeontogr. Soc., 1-80.

Savage, T. E. \& Van Tuyl, F. M. 1919: Geology and stratigraphy of the area of Paleozoic rocks in the vicinity of Hudson and James Bays. Bull. geol. Soc. Amer. 30, 339-377.

Sňajdr, M. 1980: Bohemian Silurian and Devonian Proetidae (Trilobita). Rozpr. ústred. Ust. geol. 45, $324 \mathrm{pp}$.

Thomas, A. T. 1978: British Wenlock trilobites. Part 1. Monogr. Palaeontogr. Soc., 1-56.

Thomas, A. T. 1981: British Wenlock trilobites. Part 2. Monogr. Palaeontogr. Soc., 57-99.

Tripp, R. R. 1957: The classification and evolution of the superfamily Lichacea (Trilobita). Geol. Mag. 94, 104-122.

Warburg, E. 1925: The trilobites of the Leptaena Limestone in Dalarne. Bull. geol. Inst. Upsala 17, $1-446$.

Warder, J. A. 1838: New trilobites. Am. J. Sci. 34, 377-379.

Whiteaves, J. F. 1904: Preliminary list of fossils from the Silurian (Upper Silurian) rocks of the Ekwan River, and Sutton Mill Lakes, Keewatin, collected by D. B. Dowling in 1901, with descriptions of such species as appear to be new. Ann. Rep. geol. Surv. Canada 14, 38F-59F.

Whiteaves, J. F. 1906: The fossils of the Silurian (Upper Silurian) rocks of Keewatin, Manitoba, the north eastern shore of Lake Winnipegosis, and the lower Saskatchewan River. Palaeozoic Fossils, 3, 4,5, 243-298. Geol. Surv. Canada.

Whittington, H. B. \& Evitt, W. R. 1954: Silicified Middle Ordovician trilobites. Mem. geol. Soc. Am. 59, 137 pp.

\section{Plate 1}

\section{Meroperix aquilonaris (Whiteaves, 1904)}

Fig. 1. MGUH 15.356; cephalon, dorsal view; $\times 4$.

Fig. 2. MGUH 15.357; cephalon, dorsal view; $\times 4$.

Figs 3a-c. MGUH 15.358; cephalon, oblique lateral, dorsal and ventral views; $\times 4$.

Fig. 4. MGUH 15.361; six thoracic segments, dorsal view; $\times 5$.

Fig. 5. MGUH 15.362; fragmentary pygidium, ventral view; $\times 4$.

Fig. 6. MGUH 15.360; hypostome, ventral view; $\times 6$.

Fig. 7. MGUH 15.359; free cheek, lateral view; $\times 4$.

Fig. 8. MGUH 15.363; pygidium, dorsal view; $\times 4$.

Fig. 9. MGUH 15.364; fragmentary pygidium, ventral view; $\times 2$.

Fig. 10. MGUH 15.365; pygidium, dorsal view; $\times 2$.

Fig. 11. MGUH 15.366; pygidium, dorsal view; $\times 4$.

Figs 2, 5, 7, 8, 11 from GGU sample 218855; others from GGU sample 216856. 

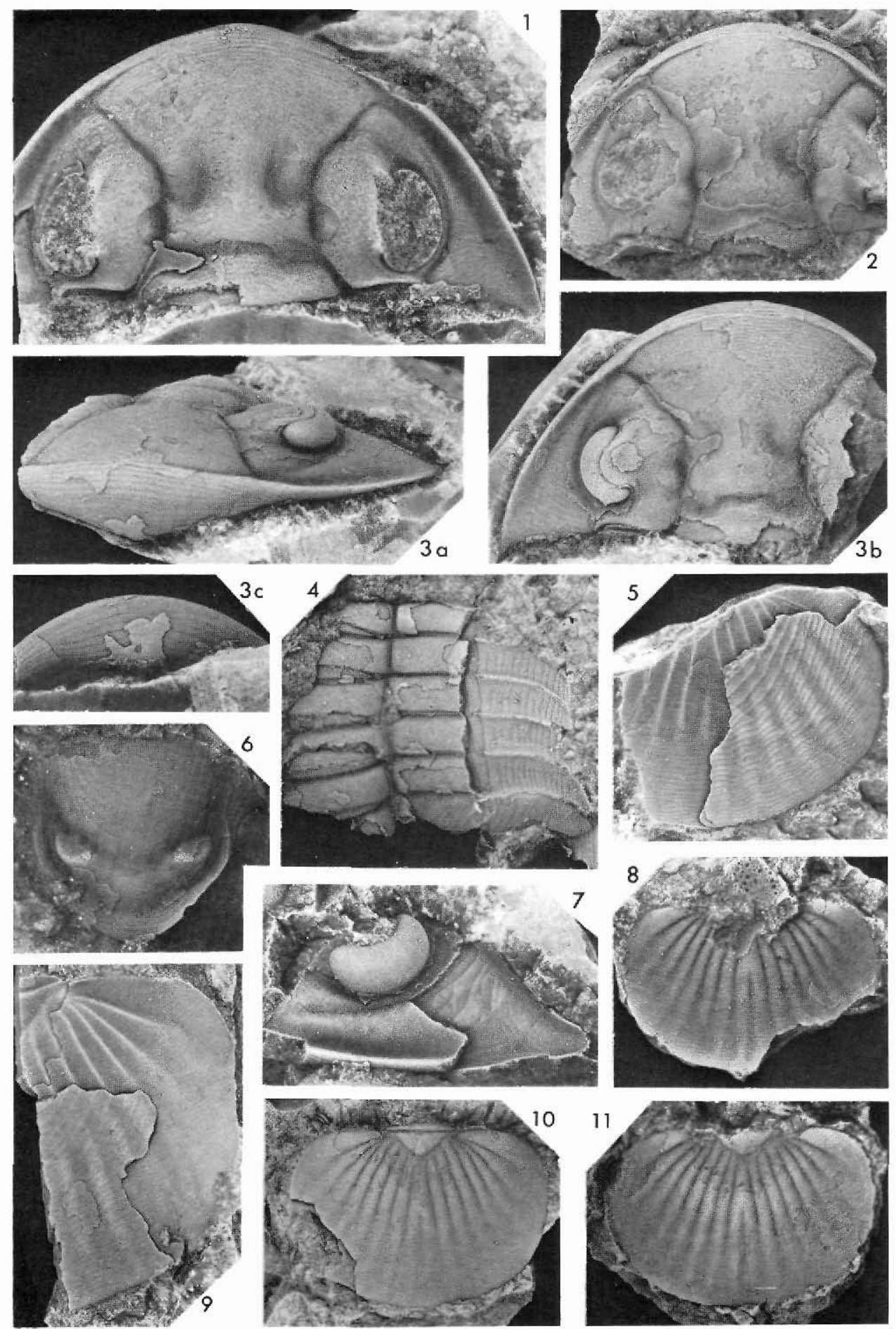


\section{Plate 2}

Xenocybe ebyconex sp. nov.

Figs 1a-c. MGUH 15.372; holotype cephalon with parts of six thoracic segments, dorsal, lateral and anterior views; $\times 6$.

Fig. 2. MGUH 15.373; paratype complete specimen lacking free cheeks, dorsal view; $\times 7$.

Fig. 3. MGUH 15.375; paratype small cranidium with coarse granulation, dorsal view; $\times 18$.

Figs 4a, b. MGUH 15.378; paratype hypostome, dorsal and lateral views; $\times 12$.

Fig. 5. MGUH 15.376; paratype free cheek with anterior part removed to show doublure and left hand connective suture, dorsal view; $\times 10$.

Fig. 6. MGUH 15.380; paratype pygidium with nine thoracic segments, dorsal view; $\times 7$.

Fig. 7. MGUH 15.374; paratype small cephalon, dorsal view; $\times 8$.

Fig. 8. MGUH 15.377; paratype free cheek, dorsal view; $\times 9$.

Fig. 9. MGUH 15.382; paratype small pygidium, dorsal view; $\times 10$.

Fig. 10. MGUH 15.381; paratype smallest pygidium, with attached thoracic segments, dorsal view; $\times$ 15.

Fig. 11. MGUH 15.379; paratype parts of four thoracic segments showing preannulus, dorsal view; $\times$ 10.

Figs 3, 8, 9 from GGU sample 216855; others from GGU sample 216856. 

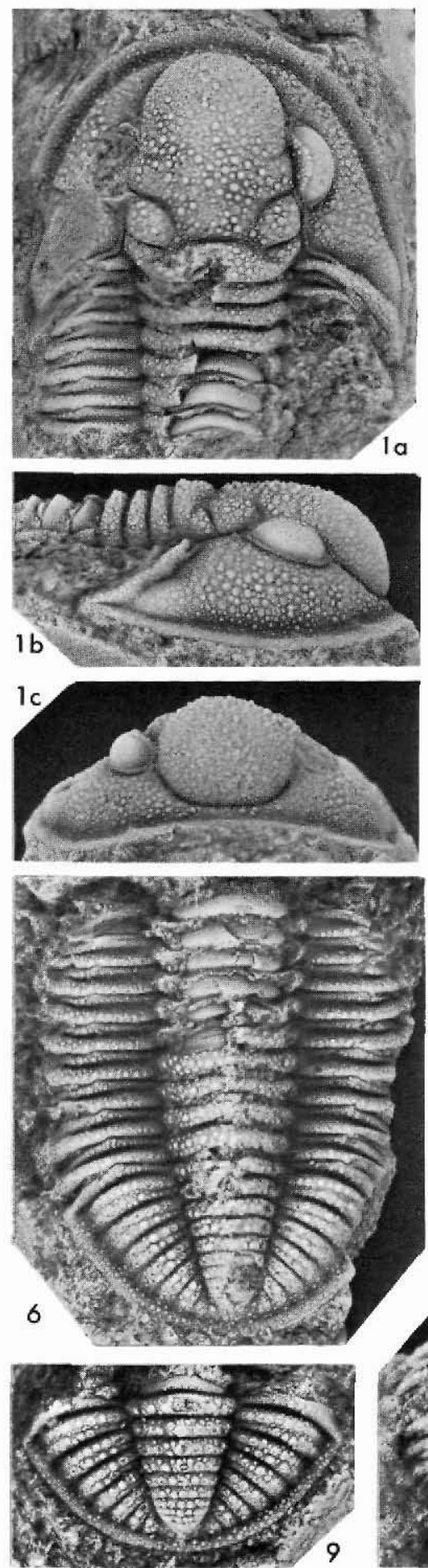
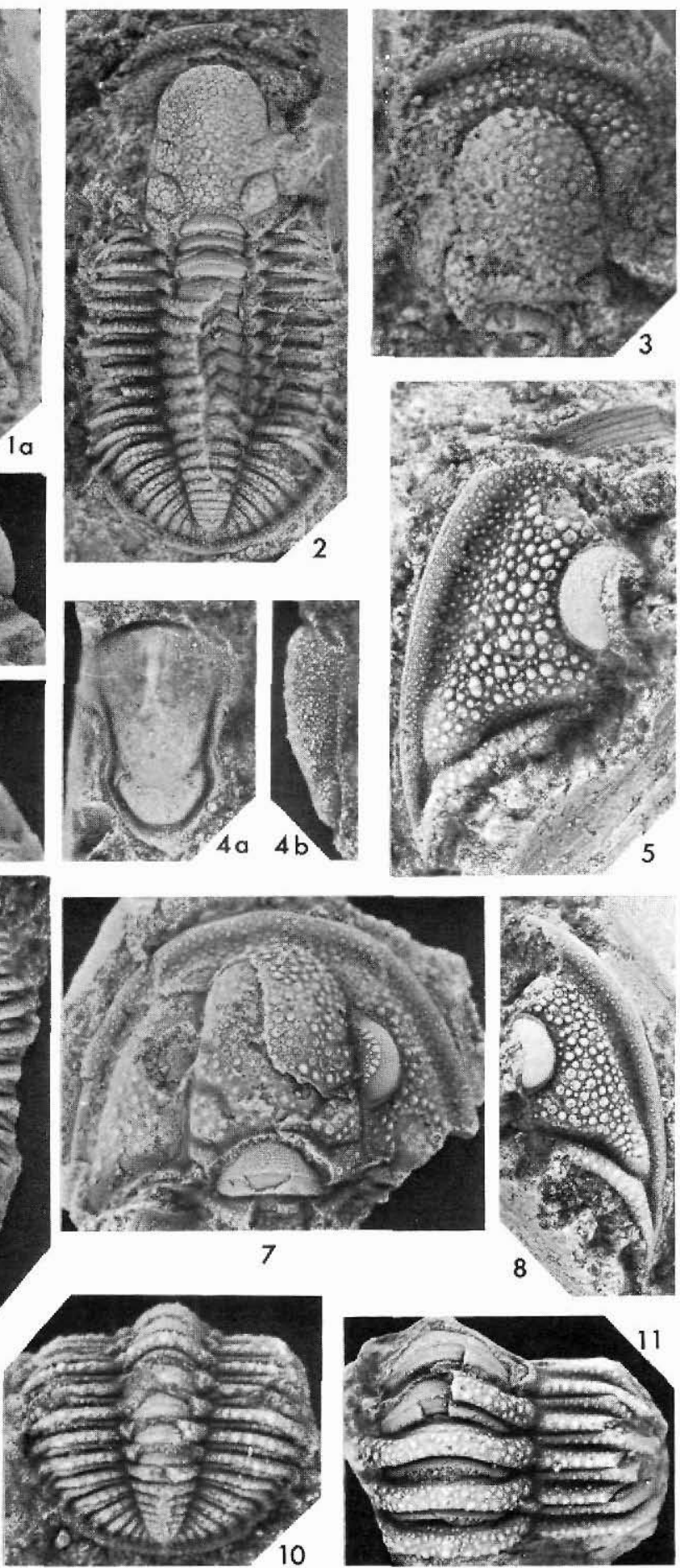


\section{Plate 3}

Xenocybe ebyconex sp. nov.

Figs 1a-c. MGUH 15.383; paratype pygidium, dorsal, posterior and lateral views; $\times 8$.

Fig. 2. MGUH 15.384; paratype pygidium, dorsal view; $\times 5$.

Bumastus? sp.

Fig. 3. MGUH 15.355; free cheek, dorsolateral view; $\times 6$.

\section{Ligiscus arcanus gen. et ap. nov.}

Figs 4a-d. MGUH 15.367; holotype cephalon, dorsal, oblique lateral, ventral and lateral views; $\times 6$.

Figs 5a-d. MGUH 15.368; paratype cephalon, dorsal, ventral, oblique lateral and anterior views; $\times 6$.

Figs 6a, b. MGUH 15.369; paratype cephalon, dorsal and oblique lateral views; $\times 6$.

Fig. 7. MGUH 15.370; paratype cranidium, dorsal view; $\times 8$.

Fig. 8. MGUH 15.371; paratype pygidium, dorsal view; $\times 8$.

Figs 4, 8 from GGU sample 216855; others from GGU sample 216856. 

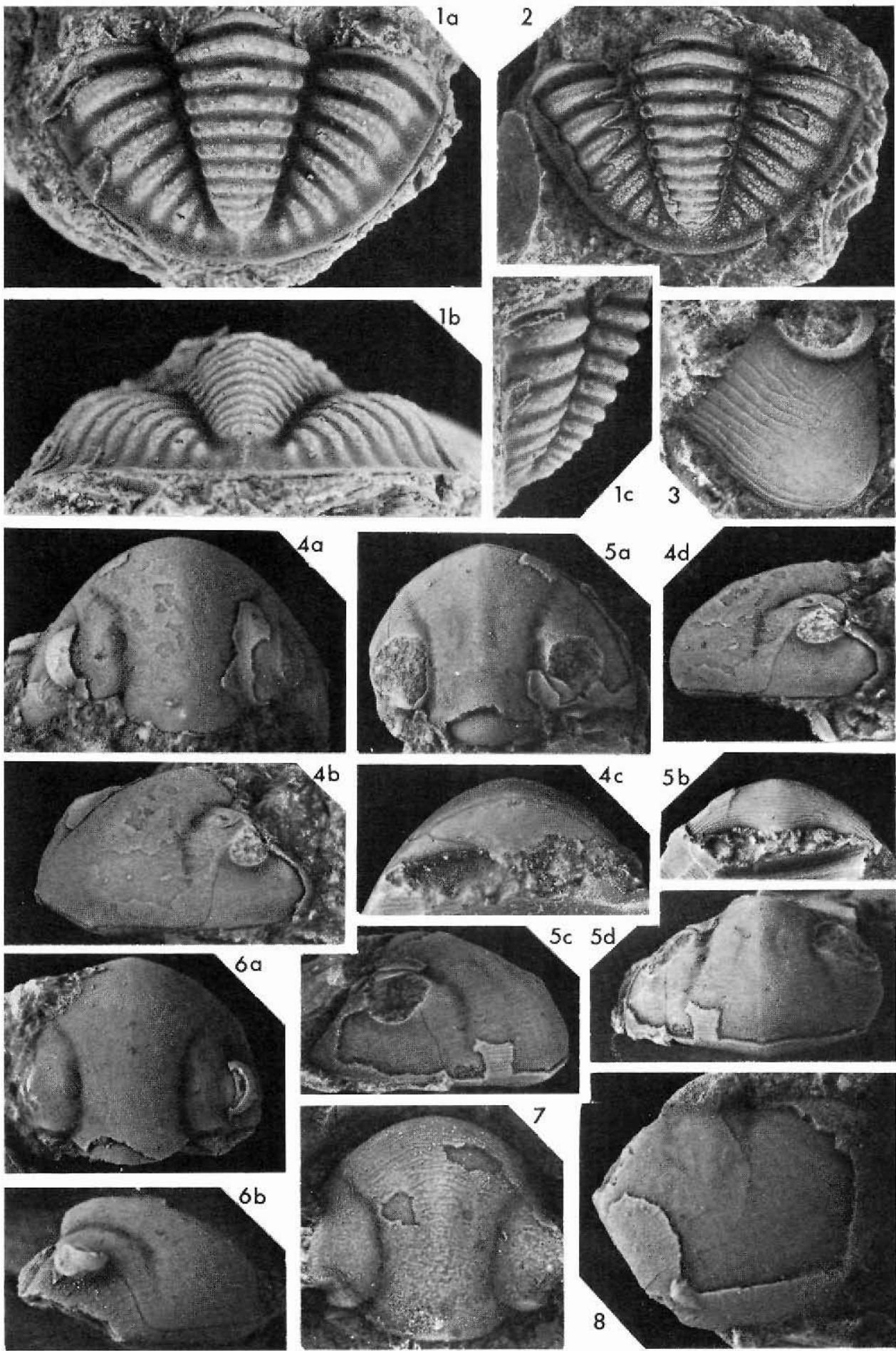

5 Rapport nr. 108 


\section{Plate 4}

\section{Sphaerexochus centeo sp. nov.}

Figs 1a-c. MGUH 15.388; paratype cranidium, dorsal oblique lateral and anterior views; $\times 4$.

Fig. 2. MGUH 15.387; paratype cephalon, oblique lateral view; $\times 4$.

Figs 3a, b. MGUH 15.389; paratype cranidium, dorsal and lateral views; $\times 4$.

Figs 4a, b. MGUHH 15.396; paratype thoracic segment, oblique lateral and dorsal views; $\times 4$.

Fig. 5. MGUH 15.397; paratype three thoracic segments, dorsal view; $\times 4$.

Figs 6a, b. MGUH 15.390; paratype cranidium, anterior and lateral views; $\times 4$.

Fig. 7. MGUH 15.393; paratype hypostome, ventral view; $\times 4$.

Fig. 8. MGUH 15.391; paratype cranidium, anterolateral view; $\times 4$.

Fig. 9. MGUH 15.394; paratype hypostome, ventral view; $\times 4$.

Fig. 10. MGUH 15.392; paratype cranidium, dorsal view; $\times 4$.

Figs 12 a, b. MGUH 15.386; holotype pygidium, dorsal and plan views; $\times 4$.

Fig. 13. MGUH 15.395; paratype hypostome, ventral view; $\times 4$.

Fig. 14. MGUH 15.398; paratype pygidium, dorsal view; $\times 3$.

Fig. 15. MGUH 15.399; paratype pygidium, plan view; $\times 4$.

\section{Sphaerexochus centeo? sp. nov.}

Fig. 11. MGUH 15.400; hypostome, ventral view; $\times 4$.

Figs 3-7, 9-15 from GGU sample 216855; others from GGU sample 216856. 

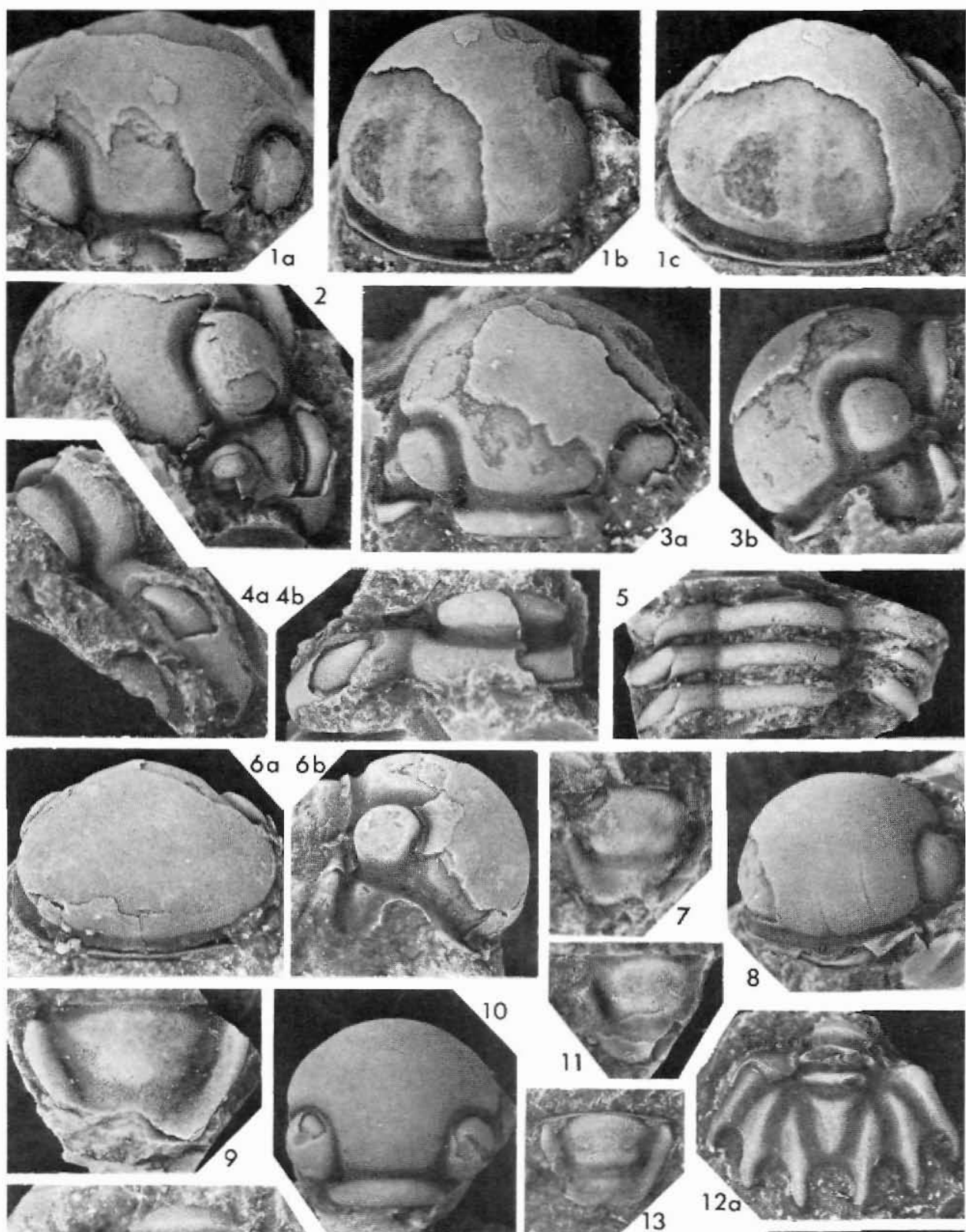

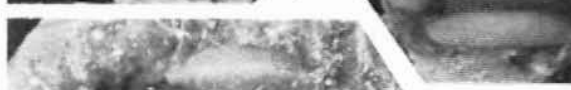
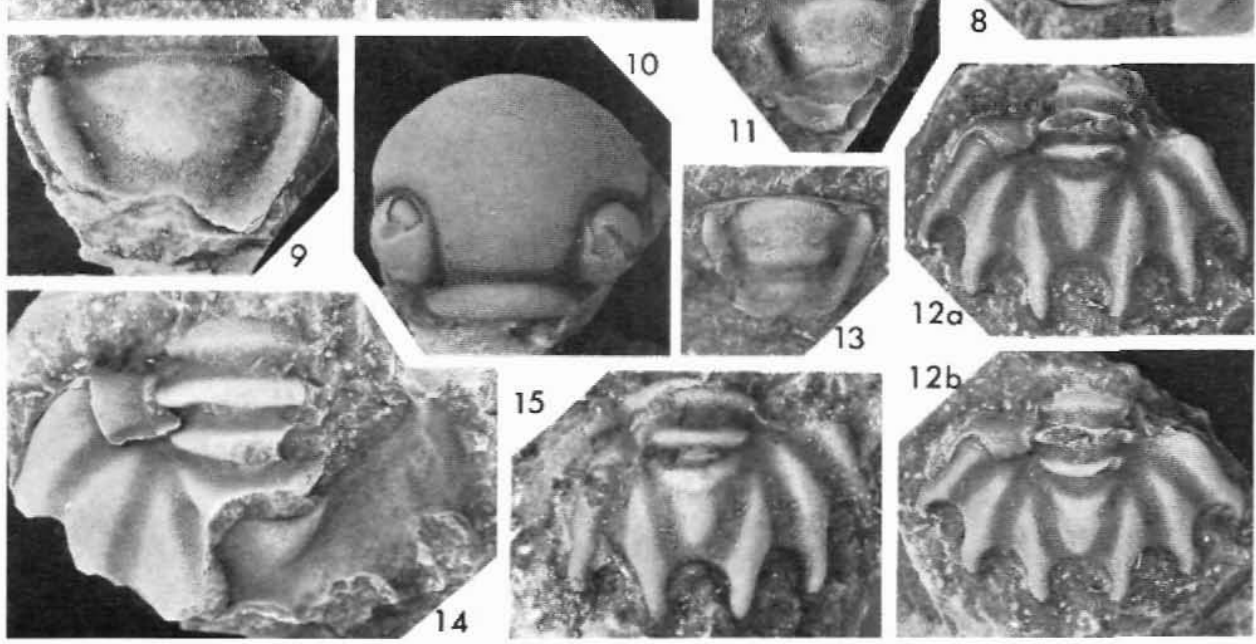


\section{Plate 5}

Hyrokybe meliceris sp. nov.

Figs 1a, b. MGUH 15.402; paratype cephalon, dorsal and oblique lateral views; $\times 6$.

Figs 3a-c. MGUH 15.401; holotype cephalon with rostral plate and hypostome in place, oblique lateral, dorsal and ventral views; $\times 3$.

\section{?trilobite fragment}

Fig. 2. MGUH 15.408; plan view; $\times 8$.

\section{Dicranogmus? sp.}

Figs 4a-c. MGUH 15.403; cephalon, dorsal, anterior and lateral views; $\times 3$.

Fig. 6. MGUH 15.405; pygidium, dorsal view; $\times 3$.

Fig. 7. MGUH 15.404; hypostome, ventral view; $\times 3$.

\section{Scotoharpes? sp.}

Fig. 5. MGUH 15.385; fringe fragment, ventral view; $\times 3$.

\section{Ceratocephala cf. C. bicuspis (Angelin, 1854)}

Fig. 8. MGUH 15.406; cephalon, anterior oblique view; $\times 8$.

Figs 9a, b. MGUH 15.407; cephalon, dorsal and anterior oblique views; $\times 4$.

Figs 2, 5-9 from GGU sample 216855; others from GGU sample 216856. 

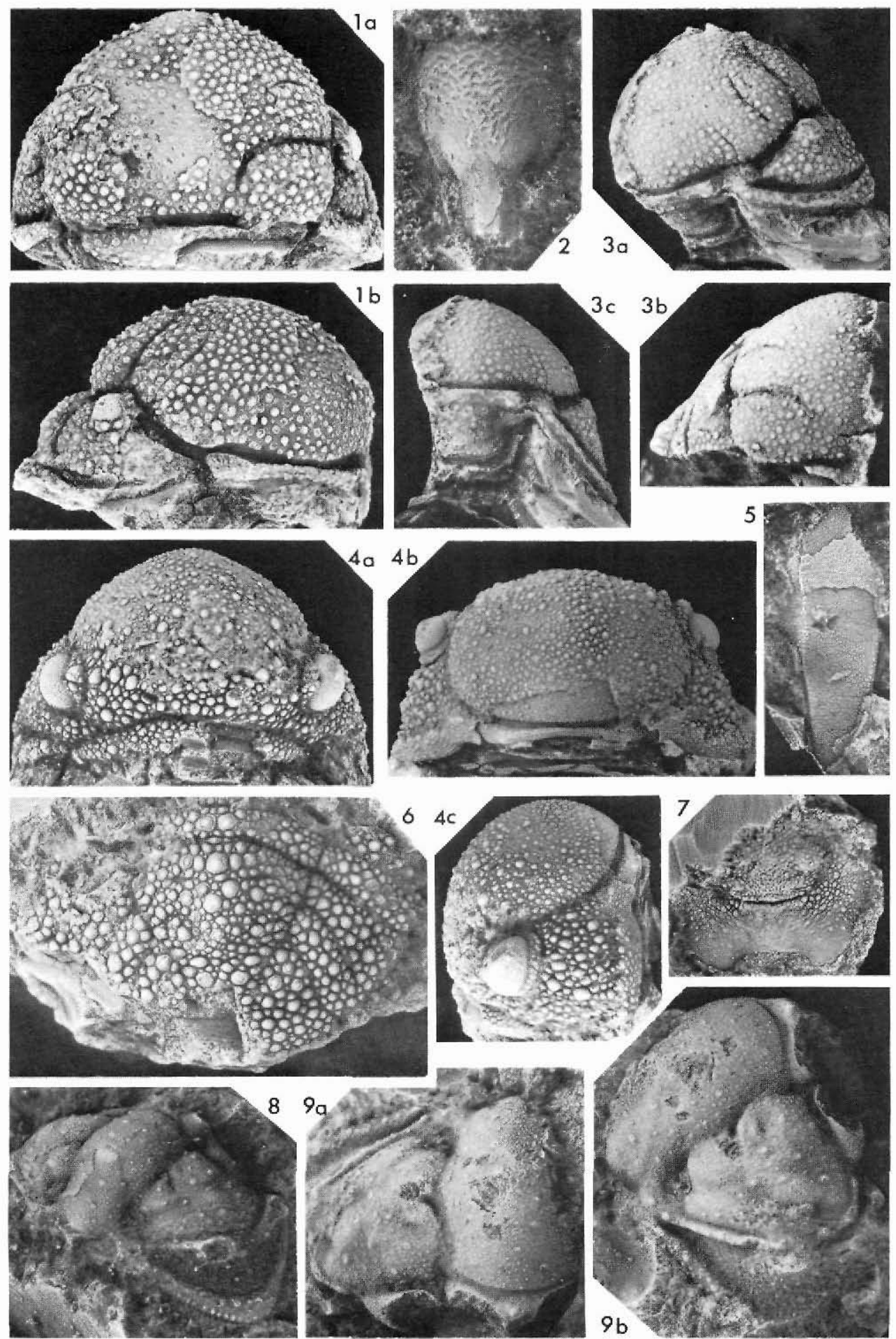